\title{
BIOETHICAL POSITIONING OF SPANISH HEALTH PROFESSIONALS: A SEMI-QUANTITATIVE STUDY
}

\author{
Marta Elena Losa Iglesias ${ }^{1}$, Ricardo Becerro de Bengoa Vallejo ${ }^{2}$
}

\begin{abstract}
The present study was undertaken to examine the positions of Spanish health professionals on a variety of bioethical issues and to determine the relationships between these positions and the professionals' religious beliefs and political views. The study sample consisted of 50 individuals randomly selected from a database of Spanish health professionals who had received solid training in bioethics. A structured questionnaire was designed that contained six closed questions on positions on biomedical advances and science and biotechnology (eugenics, use of nonimplanted embryos for experimental purposes, human cloning, and the idea that science should have limits) and the respondents' sociopolitical and religious views, and assessment scales were developed for the responses. The distribution of the responses was subjected to statistical analysis using analysis of variance (ANOVA). For the items with responses scored on a Likert scale, the positions taken were moderately adverse, and the vast majority of respondents believed that there should be limits to science. Religious convictions had greater influence on the responses than political orientation. There was evidence that liberal beliefs corresponded with what the authors consider to be more progressive ideas about the bioethics issues addressed in the study. The important questions of bioethics require an interdisciplinary approach and a combination of state and private-sector action to strengthen the links between religion and science, keep general knowledge up to date, and properly train biotechnology professionals.
\end{abstract}

Key words: bioethics, health professionals, Spain

Posición bioética de profesionales de la salud de España: Un estudio semi-cuantitativo

Resumen: Se realizó el presente estudio para examinar las posiciones de profesionales de la salud española sobre una variedad de temas bioéticos y determinar las relaciones entre estas posiciones y las creencias religiosas y puntos de vista políticos de los profesionales. La muestra del estudio consistió de 50 individuos seleccionados al azar de una base de datos de profesionales de la salud en España que habían recibido formación sólida en bioética. Se diseñó un cuestionario estructurado con seis preguntas cerradas sobre posiciones acerca de avances biomédicos, de ciencia y biotecnología (eugenesia, uso de embriones no implantados para propósitos experimentales, clonación humana y la idea de que la ciencia debería tener límites), y los puntos de vista sociopolíticos y religiosos de los respondientes, y se desarrollaron escalas de evaluación para las respuestas. Se sometió la distribución de las respuestas a análisis estadístico usando análisis de varianza (ANOVA). Para los elementos con respuestas valuadas con una escala Likert, las posiciones tomadas fueron moderadamente adversas y la inmensa mayoría de los respondientes creían que debería haber límites para la ciencia. Las convicciones religiosas tuvieron mayor influencia en las respuestas que la orientación política. Hubo evidencia de que las creencias liberales se correspondieron con las que el autor consideraba ideas más progresistas sobre temas de bioética abordados en el estudio. Las preguntas importantes de bioética requieren una aproximación interdisciplinaria y una combinación de acción estatal y del sector privado para fortalecer los vínculos entre religión y ciencia, mantener el conocimiento general actualizado y formar apropiadamente a los profesionales de la biotecnología.

Palabras clave: bioética, profesionales de la salud, España

\section{Posicionamento bioético dos profissionais de saúde espanhóis: Um estudo semi-quantitativo}

Resumo: O presente estudo foi realizado para examinar a posição de profissionais de saúde da Espanha sobre uma variedade de temas bioéticos e determinar a correlação entre estas posições e crenças religiosas dos profissionais e pontos de vista políticos. A amostra estudada consistiu de 50 indivíduos selecionados aleatoriamente da base de dados de profissionais de saúde da Espanha que receberam sólido treinamento em bioética. Um questionário estruturado foi definido para conter seis questóes fechadas sobre posiçôes a cerca de avanços biomédicos, ciência e biotecnologia (eugenia, utilização de embriôes não implantados para projetos experimentais, clonagem humana e a ideia de que a ciência deveria ter limites) e os pontos de vista sociopolítico e religioso dos respondentes, e escalas de avaliação foram desenvolvidas para as respostas. A distribuição das respostas foi objeto de análises estatísticas utilizando a análise de variância (ANOVA). Para os itens com respostas computadas pela escala de Likert, desde de 'concorda fortemente' a 'discorda fortemente', as posiçóes tomadas foram moderadamente adversas, e a vasta maioria dos respondentes acreditaram que deveria haver limites para a ciência. Convicçôes religiosas tiveram maior influência nas respostas do que aquelas de orientação política. Houve evidência de que crenças liberais corresponderam com o que os autores consideram ser ideias mais progressistas sobre temas bioéticos direcionados pelo estudo. As importantes questóes de bioética requerem uma abordagem interdisciplinar e uma ação combinada dos setores público (estatal) e privado para revigorar os elos entre religiáo e ciência, manter um conhecimento geral atualizado, e treinar adequadamente profissionais em biotecnologia.

Palavras-chave: bioética, profissionais de saúde, Espanha

\footnotetext{
${ }^{1}$ Facultad de Ciencias de la Salud, Universidad Rey Juan Carlos, Madrid, Spain Correspondence: marta.losa@urjc.es

${ }^{2}$ Escuela de Enfermería, Fisioterapia y Podología, Universidad Complutense de Madrid, Spain
} 


\section{Introduction}

In today's rapidly changing world, the prevailing values are also subject to constant evolution. Advances in technology, the emergence of a knowledge-based society that demands continual learning, and new patterns of work requiring ever-deeper levels of expertise all force society as a whole, as well as its constituent family units and individuals, to continually readjust their conceptions of the various issues related to bioethics. In essence, we are faced with what Kuhn(1) in 1996 called a 'paradigm shift': a radical transformation in the predominant mode of thinking or acting scientifically. The entire structure of concepts that previously appeared solid and secure has begun to sway and blur. The structure must undergo a complete revision, as the processes of change have 'phagocytosed' its concepts, leaving them unfit to explain the new reality of scientific thought.

The paradigm of bioethics and its principles as a discipline were set forth in the classic study of Beauchamp and Childress(2). Bioethics is a system of moral argument with four levels of justification - theories, principles, rules, and individual cases or judgments - applied to resolve moral conflicts and dilemmas encountered in clinical experience. The field of medicine has traditionally been reluctant to participate in interdisciplinary dialogue; in response to its tendency to conceive of bioethics solely as biomedical ethics, there emerged thinkers and movements whose orientation was toward a broader, more inclusive conception of bioethics. An example is Potter(3), who advocated a universal approach to human health that serves all of the globe's inhabitants, not just the 'chosen', with low mortality rates and human reproduction controlled at will(4).

In reviewing the literature, we found that previous research and writing on bioethics has focused primarily on its social $(5,6)$ and psychological $(7)$ implications. Relatively little work has been done on the differences between the various classes of concepts and values that are coming to dominate different cultures and societies. Indeed, anthropologically and from a clinical and general healthcare standpoint, these cultures are becoming increasingly interrelated, as shown by the studies of Hurst et al.(8) in Europe and of Duval et al.(9) in the United States.
Given this context, the idea behind the present work was to examine and evaluate the problems that arise in the field of bioethics by exploring the differences expressed by members of a society that is part of the developed world: Spain. We consider the present situation and current trends in this country with respect to a number of controversial issues that reflect cultural and ideological changes that are taking place in its society. The objective was to discover factors underlying differences in how individuals respond to demands placed on them in their daily work. In particular, we sought to explore the concerns of a group of health-care professionals related to issues raised by advances in scientific knowledge, and the relationship of their religious and political views to the positions they took on bioethics issues such as eugenics and human cloning. The data collected could then be used by other researchers considering bioethical problems. The anthropological approach taken in the analysis allows observation of the similarities and differences among the participating individuals.

This work is also a response to the need for stronger links among the global environment, the world of science, and the world of religion as crucial factors in any country's economic and cultural development. Considering the relationships among these factors can help establish the appropriate conditions for the implementation of projects in bioethics that tend to humanize scientific research, and to reduce the extreme and irrational positions that can work against the steady process of humanization of mankind.

\section{Materials and methods}

Taking into account the differences among groups of people in terms of educational level, social responsibility, influence in shaping public opinion and professional knowledge of and concern about the issues involved, we selected health professionals in Spain as the participants in this study. Earlier research on the views of health professionals can serve as a basis for determining the similarities and differences in how they perceive the issues, as well as the attitudes they take toward them. This type of homogeneous cross-sectional study can also stimulate similar studies within the societies of other countries of the European 
Union and the developed world and thus help determine the respective positions of Western and predominantly Christian societies on the ethical questions raised. The choice of health professionals to participate in this study was therefore very deliberate. By virtue of their training, they have extensive knowledge of the scope of current and proposed legislation and how it is applied. Indeed, their professional activities are directly affected by such legislation, as they are the final link in the decision-making chain, and it is not uncommon for a problem presented by a patient to involve ethical considerations in addition to clinical ones(10).

The study sample consisted of 50 Spanish health professionals chosen by simple random selection from a database of health professionals who had received solid training in bioethics and were invited to participate in the study. As a member of Spanish society, each of these individuals brought a unique set of cultural baggage, ethos, and specific worldview to the study. Their common link is their professional involvement with the world of health care. The sample encompassed several different health professions. All of these types of health-care professionals have traditionally had a solid educational foundation in various aspects of bioethics and their application to everyday practice. Indeed, their academic curriculum would have included instruction in such areas as professional ethics and deontology(11). In addition to their usual training, the respondents had also taken postgraduate and professional specialization courses in this discipline, such as master's degree studies in bioethics.

A quantitative method was used to objectively describe and analyze how Spanish society is coming to terms with current advances in biomedicine. The aim of using this methodological approach was to collect information on facts, events, opinions, and values of the study participants. The specific quantitative technique used was a survey. A structured questionnaire was designed that contained closed questions, and assessment scales were developed for the responses to cover the various objectives of the study. The respondents were given the opportunity to explain their responses to each question. This additional information, which was analyzed separately, provided a more open element to the survey, yielding data on the background underlying the positions expressed by the respondents.

The date, time, and place of the meeting where the survey would be conducted were arranged with each participant via e-mail or telephone.

Whenever a survey question elicited doubt in the respondent about the terminology used, extra information was provided orally. The respondents were also provided a glossary of definitions. The questions were arranged in groups representing major areas of bioethics. The questionnaire was brief. Questions 1 to 3 concerned important topics of debate in contemporary bioethics: eugenics, human cloning, and experimentation with embryos. Questions 4 to 6 concerned topics related to advances in biotechnology - the role of science and its possible limits - and the respondent's religious and political views that could be related to the positions they took on the other questions.

The ordinal variables that were directly quantifiable corresponded to those responses that could be ordered from greater to lesser. These were the responses to the group of questions about medical advances: Question 1, on eugenics; Question 2, on the use of human embryos; and Question 3, on human cloning. A Likert scale from 1 to 5 was used, with the lowest score corresponding to 'strongly disagree' and the highest score corresponding to 'strongly agree'. The ordinal variable that was indirectly quantifiable corresponded to Question 4, for which the options were 'yes' (considered equivalent to 'strongly agree'), 'no' (considered equivalent to 'strongly disagree'), and 'don't know' (which, while not exactly the same as 'perhaps', would clearly be located between 'yes' and 'no'). The categorical (nonquantifiable) variables corresponded to the responses to Questions 5 and 6 on beliefs and political choice, respectively. These responses cannot be represented on a numerical scale, because one political or religious option cannot be ranked higher or lower than another.

The analysis of each of the items consisted of two stages. First, the distribution of the responses was subjected to statistical analysis using analysis of variance (ANOVA). In the second stage, the re- 
sponses and their associated explanations were subjected to analysis of the arguments that they contained. This second stage allowed the analysis to be enriched by the respondents' personal opinions about issues that are deeply connected to their personal values and beliefs.

The following software programs were used for data collection and statistical analysis: SPSS version 19.0 (SPSS Science, Chicago, IL) and Microsoft Excel version 11.5612.5606 (Microsoft Corp., Redmond, WA).

Each participant in the study was provided with a detailed explanation of the nature of the investigation, and each respondent read and signed an informed consent form before completing the questionnaire.

\section{Results}

The study sample consisted of 50 individuals (21 females and 24 males), almost the $50 \%$ per sex variable. The sample encompassed several different health professions: $70 \%$ were graduates in medicine or surgery, $10 \%$ were registered nurses, $10 \%$ were graduates in dentistry, $5 \%$ were podiatrists, and $5 \%$ were physiotherapists.

\section{Question 1}

In response to the question on eugenics, $32 \%$ of the respondents were neither in agreement nor in disagreement, $28 \%$ expressed disagreement, nor $24 \%$ expressed agreement.

The distribution of responses has the characteristics of a normal distribution. The median and mode correspond to the response 'neither agree nor disagree', indicating that the views are very divided or that no definite position is taken.

Analysis of the respondents' explanations showed that they held a moderately adverse position. Those who opted for the negative side of the scale took the opportunity to give justifications for their responses and showed greater knowledge or concern about the origins and implications of eugenics. They argued that eugenics is not bad in itself, but that the problem arises when it is used for certain ends such as discrimination, or to exercise a policy of racism. The participants who responded in this way do not believe in the 'good intentions' of those currently working on eugenics projects. Nonetheless, a significant percentage of the respondents see eugenics as a viable and valuable tool when applied to the prevention of diseases.

\section{Question 2}

In response to the question on use of human embryos, $46 \%$ of the respondents agreed with their use for experimentation, and 38\% disagreed (more or less strongly), with $12 \%$ holding a neutral position.

The distribution of responses revealed no notable pattern, with the views being fairly diversified. Most of the respondents who held a position on the positive side of the scale chose the moderate option. The density curve shows more data on the positive side of the responses and has two peaks, one for each of the moderate responses ('disagree' and 'agree').

Those who opted for the negative side of the scale and the intermediate option (together constituting half of the sample) offered more explanation for their responses. They were critical of indiscriminate experimentation with embryos, suggesting that it is a first step toward experimentation with implanted embryos, and that this extreme 'scienticistic' conception of embryo research ran the risk of misuse by those who promote totalitarian or discriminatory ideologies. Some on this negative side of the responses believed that none of the results of this research have led to any scientific progress at all. In contrast, the rationale used by most of the half who opted for the positive side of the scale was that it is precisely the scientific advances that can be achieved in both the detection and the prevention of diseases that justifies the use of embryos.

\section{Question 3}

A clear majority of the respondents were in disagreement with human cloning. The distribution of responses is concentrated on the negative side of the scale (62\% of the sample), and is proportional to an inverted chi-square. Sixteen percent of the respondents had no definite view on the 
matter, while only $22 \%$ were in favour, mostly moderately so.

Although all five values were represented, only one respondent expressed 'strong agreement' with human cloning. The density distribution curve is fairly flat, but declining, with decreasing responses as the level of agreement increases and two mild peaks at the two nonextreme values ('disagree' and 'agree').

The argument most commonly put forward in opposition to human cloning was that it could be manipulated and used for purposes that are pernicious for humanity, especially given the abundance of totalitarian regimes. Some of those opposed to cloning also argued that it is an absurd, pretentious, or senseless idea with no scientific basis. Those whose responses were on the positive side of the scale cited the possible use of cloning for therapeutic purposes as the primary justification while simultaneously questioning the supposed end of perfecting the human race.

\section{Question 4}

There was no room for doubt about the general view that science should have limits. The distribution of responses was highly concentrated, with $82 \%$ believing that science should have limits and only $2 \%$ ( 1 respondent) expressing the contrary opinion, and $16 \%$ choosing the option 'don't know'. Thus all three possible values of the variable were observed.

The most notable finding in the analysis of the explanations given in the open part of the questionnaire was the assertion that the limits to which science should be confined are those that might be identified with a nonconfessional ethic. In other words, the limits should not be imposed from outside, from some field external to science, but must come from within and be linked to professional integrity and honesty and, of course, to the beneficial and humanitarian ends of scientific research. Several respondents also stated that too many barbarities have already been committed in the name of an uncontrolled 'scientism', which perhaps has now become a cliché in the field of research, with its paradigm in the construction of the atomic bomb. Also noteworthy was that some of those who chose the 'don't know' option relativized the moral issues that arise in science, arguing that questions of ethical or moral boundaries should be left to the individual, as it can be assumed that any scientist who has reached a prominent place in society has sufficient training to differentiate right from wrong in the conduct of science. In sum, most believe in the codes of professional ethics and feel that these should impose clear limits that foster advances in knowledge that are beneficial rather than detrimental to mankind.

\section{Question 5}

As expected, the question about belief or religion revealed a predominance of Roman Catholics in the sample (72\%). In second place (16\%) were respondents who said that they had another religion, without specifying what that was in the open part of the questionnaire. Ten percent of the respondents declared themselves to be atheist, and 2\% (1 respondent) Jewish. Although this item had seven possible responses, only four of them were actually chosen by this sample of respondents, reflecting a uniformity of religion in the Spanish state.

The interest in the distribution of the respondents' professed religion is in the correlation of this variable with their responses to the other questions. Immediately notable was the lack of concordance between the values and opinions that the respondents had expressed concerning the various ethical issues related to biotechnology and the views held by the religious leaders of the faith they claimed to profess. Indeed, a majority (54\%) recognized being in disagreement with the doctrines advocated by their religious leaders in this area.

A possible clue to the reason for this discrepancy appeared in the explanations provided in the open part of the questionnaire. Many respondents reported that, in principle, they are neither religious nor accustomed to respecting rigid doctrines. They also argued that religious leaders do not necessarily hold the ideas of the majority in this area, as might be expected of a conservative religion faced with the evolution of science. Others, especially those who chose the 'don't know' 
option, added that in some matters they did agree with official doctrine while in others they did not and that, metaphorically speaking, things are not always black and white but often involve shades of gray.

\section{Question 6}

The dispersion of responses to the question on political ideology was relatively large, with $34 \%$ of respondents considering themselves conservative, $26 \%$ liberal, and $18 \%$ socialist. The substantial remainder, $22 \%$, declared themselves to hold other ideas or political positions that were not among the options listed on the questionnaire. The availability of policy options for all tastes in Spain was reflected by the distribution of responses over all of the four categories for this variable This sample of Spanish health professionals is thus markedly diverse in terms of where they stand on the political spectrum. This is consistent with the political situation in the country, where divisions among socialists, conservatives, and neoliberals are evident, although the conservatives have a fair degree of affinity with the neoliberals, despite the implausibility of that scenario. The country's political spectrum also includes a substantial segment that is atomized into small groups, as reflected in the study sample. Most of the respondents did not provide explanations for their response to this question in the open part of the questionnaire. Those who did clarified that either they did not consider themselves to be politically active or they were affiliated with some party but did not participate in its activities, with comments indicating that they held the world of politics in low regard.

\section{Differences between the religious and socio-political variables and the bioethics variables:}

A statistically significant was found between response to the eugenics question and beliefs at the $99 \%$ confidence level $(\mathrm{p}<0.01$, ANOVA). The ANOVA results shows an $\mathrm{F}$ score (the ratio of intergroup to intragroup estimates) of 4.33. The difference between the mean values for eugenics of one category of beliefs and another was statistically significant at the 95\% confidence level ( $\mathrm{p}<$ 0.05, F test).
A statistically significant correlation was found between response to the use of embryos question and beliefs at the $90 \%$ confidence level $(\mathrm{p}<0.10$, ANOVA). The ANOVA results, shows an $\mathrm{F}$ score of 0.88 . No statistically significant difference was found between the mean values for use of embryos of one category of beliefs and another at the 95\% confidence level ( $\mathrm{p} \geq 0.05$, F test).

The Levene statistic was used to test the variances, since at least one of the distributions was non-normal. The difference between the standard deviations was statistically significant at the $95 \%$ confidence level ( $p<0.05$, Levene test).

A statistically significant correlation was found between response to the human cloning question and beliefs at the $95 \%$ confidence level ( $\mathrm{p}<0.05$, ANOVA).

\section{Discussion}

Regarding eugenics, Spanish sample holding a moderately adverse posture. Those who opted for the negative segment of the scale of question demonstrated greater knowledge or concerns about the origin and implications of eugenics. In this sense argue that eugenics is not bad by itself, only is bad if people use it with racist or discriminatory purposes. As Powell(12) stated, eugenics provide a convenient rationale to oppose or dismantle social protections for disadvantaged groups.

Evaluating the statistical analysis of the data, it is clear that the sample is mostly disagreeing with human cloning. Across Europe there is great opposition to animal cloning. One of the main factors of negative reactions to the cloning of animals today is the supposed link between this type of cloning and the future reproductive cloning in humans. According to data provided by studies(13), this belief is particularly strong in Austria with an average of 7.4, Britain 7.2, and in France, Poland and Germany 7.0. The main justification for the majority of Spanish experts to oppose human cloning is a moral and alludes to the fact that the idea of cloning can lead to handling and use with pernicious purposes for humanity, especially for the existence of totalitarian regimes in the world. Moreover, the individuals who answer positively, the primary justifications were about the therapeutic purposes. 
Most respondents have an anti-abortion position. They understand that you cannot enforce the rights of the mother, on the right of the unborn. Informants who agree with abortion argue that there are many cases, such as rape or fetal malformation, which is necessary to get to the abortion.

In Spain, the Organic Law 2/2010(14) regulates certain aspects of sexual and reproductive health, and also establishes the legal regime of abortion or abortion, so although the majority of respondents disagreed, the Spanish legal rules allow abortion under some assumptions and specific deadlines. But some authors as Martinez Otero(15) found problems on the article $19.2^{\circ}$ of the Organic Law $2 / 2010(14)$, such as suspicion over conscientious objectors.

The question of euthanasia raises another problem of bioethics more generated controversy throughout the world for its deep ethical and religious implications. Foreground in the arguments used by respondents, an approach where the option chosen for application in specific cases and individuals. Some of them argue that euthanasia in terminally ill patients is justified beyond recovery or when their quality of life is severely compromised. Others suggested that in many cases the prolongation of life is a torment not only for the patient but for their families. Those opposed to euthanasia did religious precepts justifying how the sacredness of life.

In 2002, the Ethics Working Group of the German Association for Palliative Medicine(16) conducted a survey among physician in order to evaluate their attitudes towards different end-oflife medical practices, such as euthanasia, physician-assisted suicide, and terminal sedation. The results were that the vast majority was opposed to legalizing different forms of premature termination of life: $90 \%$ for euthanasia(16).

In assessing the justifications used first thing that stands out is the confirmation that the limits of science should mark only the ethics. Limits must come from within the scientific community that will evaluate the benefit / risk of the progress in each case. Any informant has an ambivalent position, understands the need of scientific progress, but understands that there is a high risk of mis- use, such as military use. Authors as Brubaker(17) explain the rational conflict that occurs in scientists to the advances of science.

With regard to religion, the first thing that strikes you on the responses, the lacks of correlation between respondents who profess religion and judgment with respect to values and opinions that support their religious leaders. In other words, there is no harmony between professed religion and personal views on various ethical and moral issues proposed in the survey related to biotechnology.

In Spain, after the disintegration of dictatorial regimen of Franco, the secularisation of Spanish society led to a steep decline in the social significance of the Church, as well as a sustained loss of religiosity among Spaniards. However, in the new political and social context of a sovereign state under the rule of law that guarantees the basic liberties of its citizens, the unifying role of the Church weakened(18).

Respect to transfer their own beliefs to their children, the arguments and justifications of most informants are based on transmit of beliefs and the respect of children's ideas. From the perspective of most respondents, it is inevitable that parents transmit their beliefs consciously or unconsciously to the children. Among those who chose negative option, appeal to personal experience, stating that it is better for children to develop their own beliefs and have their own criteria ethical "under the idea of free will.

Preferences, beliefs, and norms that govern human behaviour are formed partly as a result of genetic evolution, and partly they are transmitted through generations and acquired by learning and other forms of social interactions(19). However, there are some studies like Pinquart \& Silbereisen(20) who investigate the influence of children on parents. This study shown that the transmission of values from adolescents to parents were about the usefulness of new technology, beliefs concerning the traditional way of life and the importance of religion. 
The sample of Spanish professionals presents a remarkable diversity in terms of political ideology. This is consistent with the political situation of the country, where the division between socialists, conservatives and neoliberals is manifest. They are not affiliated with any party and your comments indicate that, in a way, now it is discredited the world of political.

Recent corruption scandals investigated by the judges with a strong presence in the mass media in recent years in Spain could have generated a widespread perception of increasing corruption and institutional disaffection reinforced by the general population(21).

Detailed analysis of the responses of the study participants revealed the following primary findings; the vast majority of the respondents believed that there must be limits to science. Overall, the responses reflected a tendency to focus on the most controversial topics of bioethics. Each case appeared to be considered on the merits of its own particular characteristics and constraints. This made it difficult to recognize any a priori position being held simply on the basis of a respondent's expressed values and religious or ethical principles. A noticeable tendency was observed for the respondents to evaluate negatively the appropriation by some governments of advances in biotechnology and biomedicine for ends detrimental to humanity, such as armed conflict. In addition, the communications media were criticized for manipulating available information, with the respondents noting that the public in general has no direct access to information about the basic questions related to these controversial topics of bioethics. This problem was noted to be worst in underdeveloped countries, indicating that these Spanish health professionals are aware and respectful of differences across cultures and traditions. Religious convictions had greater influence on the responses than political orientation. In all of the relationships analyzed, the correlation coefficients were higher in the cases that referred to religion and lower in those that referred to political orientation. With respect to political orientation, there was evidence that liberal beliefs corresponded with what we consider to be more progressive ideas about the bioethics issues addressed in this survey than other political ideologies.

\section{Study limitations}

Some possible limitations of the study should be considered. First the number of informants seems few but there are not too much professionals in Spain with solid knowledge in bioethical issues. In another hand, the questions were very generics but we want to obtain more information in the open questions about their personal opinions.

\section{Conclusion}

New challenges raised by the development of biomedicine must be addressed with suitable mechanisms for disseminating information, and each issue must be considered and evaluated individually, always taking into account respect for the human being and the individual's right to free will. The important questions of bioethics require an interdisciplinary approach and a combination of state and private-sector action to strengthen the links between religion and science, keep general knowledge up to date, and properly train professionals in the field of biotechnology. 


\section{References}

1. Kuhn TS. The Structure of Scientific Revolutions. Chicago, IL: University of Chicago Press; 1996.

2. Beauchamp TL, Childress JF. Principles of Biomedical Ethics. $5^{\text {th }}$ ed. New York, NY: Oxford University Press; 2001.

3. Potter VR. Bioethics: Bridge to the Future. Englewood Cliffs, NJ: Prentice-Hall;1971.

4. Gracia D. Fundamentos de Bioética. Madrid: Eudema; 1989.

5. Sánchez MR. Biotecnología y sociedad en el nuevo siglo. Revista de Derecho y Genoma humano 2007; 26: $249-282$.

6. Munoz E. Social perception of biotechnology: a new tool for decision making. Revista de Derecho y Genoma Humano 1999; 10: 195.

7. MacKay E, O'Neill P. What creates the dilemma in ethical dilemmas? Examples from psychological practice. Ethics \& Behavior 1992; 2(4): 227-244.

8. Hurst S A, Perrier A, Pegoraro R, et al. Ethical difficulties in clinical practice: experiences of European doctors. $J$ med ethics 2007; 33(1): 51-57.

9. DuVal G, Clarridge B, Gensler G, Danis M. A national survey of US internists' experiences with ethical dilemmas and ethics consultation. J Gener Intern Med 2004; 19(3): 251-258.

10. Braunack-Mayer AJ. What makes a problem an ethical problem? An empirical perspective on the nature of ethical problems in general practice. J Med Ethics 2010; 27(2): 98-103.

11. Fox E, Arnold RM, Brody B. Medical Ethics Education: Past, Present, and Future. Acad of Med 1995; 70(9): 761-769.

12. Powell L. Eugenics and equality: does the Constitution allow policies designed to discourage reproduction among disfavored groups?. Yale Law \& Policy Review 2012; 20(2): 481-512.

13. Pardo R, Midden C, Miller JD. Attitudes toward biotechnology in the European Union. J Biotech 2002; 98(1): 9-24.

14. Boletín Oficial del Estado Num. 55. Ley Orgánica 2/2010, de 3 de marzo, de salud sexual y reproductiva y de la interrupción voluntaria del embarazo. Access: august 12, 2013. Available at: http://www.boe.es/boe/dias/2010/03/04/pdfs/ BOE-A-2010-3514.pdf

15. Martínez Otero JM. La objeción de conciencia del personal sanitario en la nueva Ley Orgánica 2/2010, de salud sexual y reproductiva y de la interrupción voluntaria del embarazo. Cuadernos de Bioética 2010; 21(73): 299-312.

16. Müller-Busch H C, Oduncu F S, Woskanjan S, Klaschik E. Attitudes on euthanasia, physician-assisted suicide and terminal sedation. A survey of the members of the German Association for Palliative Medicine. Med, Health Care and Philos 2005; 7(3): 333-339.

17. Brubaker R. The limits of rationality (Vol. 16). Routledge; 2013.

18. Requena M, Stanek M. Impact of democratic transitions on religiosity in Spain and Poland: A period effect analysis. Documentos de Trabajo del Grupo de Estudios Población y Sociedad IV (1), Madrid 2012. Available at: www.geps.es.

19. Bisin A, Verdier T. Cultural transmission. The New Palgrave Dictionary of Economics, 2005. Access: august 14, 2013 Available at: http://www.nyu.edu/econ/user/bisina/Palgrave_culturaltransmission2.pdf

20. Pinquart M, Silbereisen RK. Transmission of values from adolescents to their parents: The role of value content and authoritative parenting. Adolescence 2004; 39(153): 83-100.

21. Villoria M, Jiménez F. La corrupción en España (2004-2010): datos, percepción y efectos. Rev Esp Invest Soc 2012; 138(1): 109-134.

Received: December 8, 2013

Accepted: December 30, 2013 